\title{
Using a moving measurement platform for determining the chemical composition of atmospheric aerosols between Moscow and Vladivostok
}

\author{
S. Kuokka ${ }^{1}$, K. Teinilä ${ }^{1}$, K. Saarnio ${ }^{1}$, M. Aurela ${ }^{1}$, M. Sillanpää ${ }^{1}$, R. Hillamo ${ }^{1}$, V.-M. Kerminen ${ }^{1}$, K. Pyy ${ }^{1}$, \\ E. Vartiainen ${ }^{2}$, M. Kulmala ${ }^{2}$, A. I. Skorokhod ${ }^{3}$, N. F. Elansky ${ }^{3}$, and I. B. Belikov ${ }^{3}$ \\ ${ }^{1}$ Finnish Meteorological Institute, Erik Palménin aukio 1, 00560, Helsinki, Finland \\ ${ }^{2}$ University of Helsinki, Department of Physical Sciences, P.O. Box 64, 00014 University of Helsinki, Finland \\ ${ }^{3}$ Obukhov Institute of Atmospheric Physics, Pyzhevsky 3, Moscow 119017, Russia
}

Received: 13 April 2007 - Published in Atmos. Chem. Phys. Discuss.: 30 May 2007

Revised: 27 August 2007 - Accepted: 10 September 2007 - Published: 21 September 2007

\begin{abstract}
The TROICA-9 expedition (Trans-Siberian Observations Into the Chemistry of the Atmosphere) was carried out at the Trans-Siberian railway between Moscow and Vladivostok in October 2005. Measurements of aerosol physical and chemical properties were made from an observatory carriage connected to a passenger train. Black carbon (BC) concentrations in fine particles $\left(\mathrm{PM}_{2.5}\right.$, aerodynamic diameter $<2.5 \mu \mathrm{m}$ ) were measured with an aethalometer using a five-minute time resolution. Concentrations of inorganic ions and some organic compounds $\left(\mathrm{Cl}^{-}, \mathrm{NO}_{3}^{-}, \mathrm{SO}_{4}^{2-}, \mathrm{Na}^{+}\right.$, $\mathrm{NH}_{4}^{+}, \mathrm{K}^{+}, \mathrm{Ca}^{2+}, \mathrm{Mg}^{2+}$, oxalate and methane sulphonate) were measured continuously by using an on-line system with a 15-min time resolution. In addition, particle volume size distributions were determined for particles in the diameter range $3-850 \mathrm{~nm}$ using a $10-\mathrm{min}$ time resolution. The continuous measurements were completed with 24-h $\mathrm{PM}_{2.5}$ filter samples stored in a refrigerator and analyzed later in a chemical laboratory. The analyses included the mass concentrations of $\mathrm{PM}_{2.5}$, ions, monosaccharide anhydrides (levoglucosan, galactosan and mannosan) and trace elements (Al, $\mathrm{As}, \mathrm{Cd}, \mathrm{Co}, \mathrm{Cr}, \mathrm{Cu}, \mathrm{Fe}, \mathrm{Mn}, \mathrm{Ni}, \mathrm{Pb}, \mathrm{Sb}, \mathrm{V}$ and $\mathrm{Zn}$ ). The mass concentrations of $\mathrm{PM}_{2.5}$ varied in the range of 4.3$34.8 \mu \mathrm{g} \mathrm{m}^{-3}$ with an average of $21.6 \mu \mathrm{g} \mathrm{m}^{-3}$. Fine particle mass consisted mainly of $\mathrm{BC}$ (average $27.6 \%$ ), $\mathrm{SO}_{4}^{2-}$ (13.0\%), $\mathrm{NH}_{4}^{+}(4.1 \%)$ and $\mathrm{NO}_{3}^{-}(1.4 \%)$. One of the major constituents was obviously organic carbon which was not determined. The contribution of $\mathrm{BC}$ was high compared with other studies made in Europe and Asia. High concentrations of ions, BC and particle volume were observed between Moscow and roughly $4000 \mathrm{~km}$ east of it, as well as close to Vladivostok, primarily due to local anthropogenic sources. In the natural background area between 4000 and $7200 \mathrm{~km}$
\end{abstract}

Correspondence to: $\mathrm{K}$. Teinilä

(kimmo.teinila@fmi.fi) away from Moscow, observed concentrations were low, even though local particle sources, such as forest fires, occasionally increased concentrations. During the measured forest fire episodes, most of the aerosol mass appeared to consist of organic particulate matter. Concentrations of the biomass burning tracers levoglucosan, oxalate and potassium were elevated close to the forest fire areas observed by the MODIS satellite. The polluted air masses from Asia seem to have significant influences on the concentration levels of fine particles over south-eastern Russia.

\section{Introduction}

Atmospheric aerosol particles have significant influences on our environment and the quality of our life. In global and regional scales, aerosol particles have a potential to affect climate and hydrological cycle (Ramanathan et al., 2001; Penner et al., 2006; Yu et al., 2006). More locally, and especially in polluted urban environments, aerosol particles deteriorate visibility and have adverse effects on human health (Watson, 2002; Pope and Dockery, 2006). Better understanding of these aerosol effects requires detailed information on how aerosol particles originating from different sources are distributed in the atmosphere and how the chemical and physical properties of particles vary from location to location. Until now, very little is known about the concentrations and chemical composition of aerosol particles over the Russian territory. Such information would be of great interest for several reasons. First, there are large urban areas and industrial complexes in Russia with poorly known but potentially large emissions of anthropogenic aerosol particles. Aerosol measurements downwind of such sources would be of great benefit for global aerosol modelers, as well as for people planning

Published by Copernicus Publications on behalf of the European Geosciences Union. 


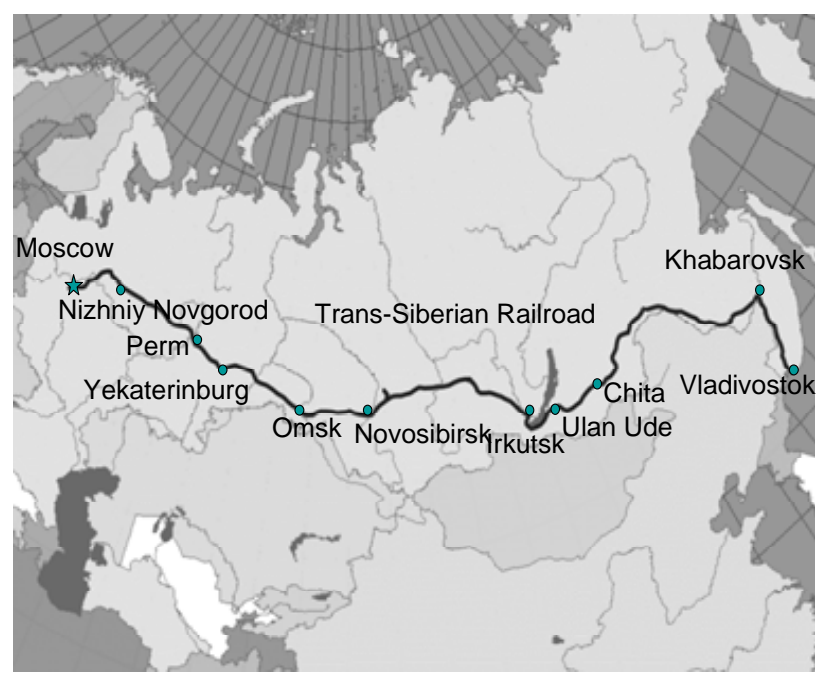

Fig. 1. The route of the expedition from Moscow to Vladivostok and back.

air quality regulations in Russia. Second, most of the Earth's boreal forests are located in Russia. A recent analysis based on long-term aerosol measurements demonstrated that boreal forests in Northern Europe produce large quantities of natural aerosol particles into the atmosphere (Tunved et al., 2006). Whether forests in Russia are capable of doing the same cannot be verified without detailed aerosol measurements there. Third, aerosol particles formed by agricultural and forest fires in Russia can, under suitable meteorological conditions, deteriorate seriously the air quality all the way through Europe and over high Arctic areas (e.g. Saarikoski et al., 2007; Stohl et al., 2007). Aerosol measurements in the vicinity of these fire spots would be of great help in developing operational systems by which such air pollution episodes could be predicted in the future.

In this paper, we present results from aerosol measurements conducted using a carriage mobile laboratory in a moving passenger train in Russia. The measurement campaign lasted for two weeks, during which period we traveled roughly a $10000-\mathrm{km}$ transect from Moscow to Vladivostok and back. The measurements discussed here include fine particle mass and volume concentration and the chemical composition of fine particulate matter. Both on-line measurement techniques and more traditional filter-based sampling methods were used. The main objective of this paper is to provide, for the first time ever, experimental information on aerosol chemistry over a relatively large geographical area in Russia. In this regard, we will investigate how the $\mathrm{PM}_{2.5}$ concentration and its chemical composition varied between urban, rural and remote areas encountered during the trip, and how our observations compare with similar measurements made earlier in Europe, Northern America and major Asian cities. We will further illustrate that despite their complexity and associated problems, rapid on-line chemical techniques, such as
Particle Into Liquid Sampler (PILS), are applicable in moving measurement platforms and have real advantages over more traditional sampling techniques.

\section{Measurements}

\subsection{Description of the campaign}

The TROICA-9 expedition continued the series of Transcontinental Observations Into the Chemistry of Atmosphere train-based campaigns having occurred since 1995 (e.g. Crutzen et al., 1998; Oberlander et al., 2002). The expedition started on 4 October 2005, from Moscow and reached Vladivostok on 10 October 2005. The journey from Vladivostok back to Moscow started on 11 October and ended on 18 October. Figure 1 shows the course of the Trans-Siberian railway from Moscow to Vladivostok over the distance of $9200 \mathrm{~km}$.

An observatory carriage was coupled to a passenger train just behind the electric locomotive, and it was equipped with several instruments measuring aerosol particles and trace gases. The TROICA-9 expedition was the second campaign that had been carried out on the new laboratory carriage elaborated and manufactured at the Torzhok carriage plant in Russia with a specific purpose of making atmospheric measurements. The Obukhov Institute of Atmospheric Physics in Russia had instruments for measuring meteorological parameters and trace gas concentrations. A global positioning system (GPS) was used to determine the accurate location of the train. Events such as forest fires and observed settlements were marked on a diary. Aerosol chemical and physical measurements were made by the Finnish Meteorological Institute and University of Helsinki. Most of the measurements were made with a high temporal resolution.

\subsection{Instrumentation and chemical analyses}

The sample air for aerosol measurements was taken from the roof of the carriage. We estimated that when the average train speed was $80 \mathrm{~km} / \mathrm{h}$ and the bulk flow rate of the aerosol sampling system was $38.41 \mathrm{~min}^{-1}$, the sampling flow would be close to isokinetic with a $6 \mathrm{~mm}$ diameter tube. The aerosol instruments were connected to an uninterruptible power system (UPS) in order to avoid breaks in measurements.

The black carbon (BC) concentration was measured with a 5-min time resolution using a dual-wavelength aethalometer (model AE-42, Magee Scientific; Hansen et al., 1984) with a flow rate of $51 \mathrm{~min}^{-1}$. The aethalometer operates at $370 \mathrm{~nm}$ (UV channel) and $880 \mathrm{~nm}$ (IR channel) wavelengths, and it was equipped with a cyclone removing particles larger than $2.5 \mu \mathrm{m}$ in aerodynamic diameter. The aethalometer collects particles onto a quartz fiber filter and measures the attenuation of light simultaneously for both wavelength channels. The method uses an inverse-lambda relationship in order to scale the UV channel data relative to the IR channel. The 
assumed absorption cross-section was $39.5 \mathrm{~m}^{2} \mathrm{~g}^{-1}$ for the $370 \mathrm{~nm}$ channel, and $16.6 \mathrm{~m}^{2} \mathrm{~g}^{-1}$ for the $880 \mathrm{~nm}$ channel. The BC absorbs strongly in both IR and UV regions. In the near UV region also many aromatic organic species have a strong absorbance. Such aromatics can be found, for example, in wood smoke and in fresh diesel exhaust.

The ionic composition of aerosol particles was measured using a Particle Into Liquid Sampler (PILS; Metrohm Peak Inc; Orsini et al., 2003) coupled with two ion chromatographs (IC) for direct on-line analysis of the collected sample. A virtual impactor (VI; Loo and Cork, 1988) was used to remove particles larger than $2.5 \mu \mathrm{m}$ in aerodynamic diameter from the sampled air. The major flow of the VI $\left(151 \mathrm{~min}^{-1}\right)$, carrying only the fine fraction (particles smaller than $2.5 \mu \mathrm{m}$ ) of aerosol particles with it, was fed into the PILS system. Annular denuders (URG) in series upstream of the PILS were used to remove acidic gases and ammonia from the sample air. Two denuders were coated using a $\mathrm{KOH}(1 \%)$ solution and one denuder was coated using a $\mathrm{H}_{3} \mathrm{PO}_{4}(3 \%)$ solution. Inside the PILS aerosol particles are grown into droplets inside a cavity that contains water vapor. After the cavity the droplets are impacted onto a collection plate. The impaction plate is washed off with a steady stream of transport liquid containing an internal standard $(\mathrm{LiF})$ and delivered into two sample loops $(1000 \mu \mathrm{l})$, one for anions and the other for cations. The samples were analyzed simultaneously using two Dionex ICS-2000 ion chromatographs (Dionex, Sunnyvale, USA). The anions were analyzed using a $4 \times 250 \mathrm{~mm}$ AS-18 analytical column, $4 \times 50 \mathrm{~mm}$ AG-18 guard column, $4 \mathrm{~mm}$ ASRS-ULTRA II suppressor, CR-ATC anion trap column and potassium hydroxide eluent generator. An isocratic run, having the hydroxide ion concentration of $39 \mathrm{mM}$ and the eluent flow rate of $1.0 \mathrm{ml} \mathrm{min}^{-1}$, was used for the anion analysis. The cations were analyzed using a $4 \times 250 \mathrm{~mm}$ CS12A analytical column, $4 \times 50 \mathrm{~mm}$ CG-12A guard column, $4 \mathrm{~mm}$ CSRS-ULTRA II suppressor, CR-CTC cation trap column and methanesulphonic acid eluent generator An isocratic run with $20 \mathrm{mM}$ MSA and eluent flow rate of $1.2 \mathrm{ml} \mathrm{min}^{-1}$ was used for the cation analysis. Concentrations of $\mathrm{Cl}^{-}, \mathrm{NO}_{3}^{-}, \mathrm{SO}_{4}^{2-}, \mathrm{Na}^{+}, \mathrm{NH}_{4}^{+}, \mathrm{K}^{+}, \mathrm{Ca}^{2+}, \mathrm{Mg}^{2+}$, oxalate and methane sulphonate (MSA) were quantified with a time resolution of $15 \mathrm{~min}$. The uncertainty of the IC analysis connected with the PILS has been estimated to be $5 \%$, even though higher uncertainties can be encountered close to the detection limit. The level of noise in the baseline was negligible in this instrumental set-up, so the limit of detection was estimated to be $0.3 \mathrm{ng} \mathrm{ml}^{-1}$ for all the ions analyzed. This is equivalent to the concentration of approximately $0.005 \mu \mathrm{g} \mathrm{m}^{-3}$ in the air.

A VI identical to that used in connection with the PILS was used to collect samples for gravimetric and chemical analysis. The VI divides the sample air into fine (aerodynamic particle diameter $\mathrm{D}_{p}<2.5 \mu \mathrm{m}$ ) and coarse fractions $\left(2.5 \mu \mathrm{m}<\mathrm{D}_{p}<8 \mu \mathrm{m}\right)$. The particles were collected on polytetrafluoroethylene (PTFE) filters (diameter $47 \mathrm{~mm}$, pore size
$3 \mu \mathrm{m}$, type FS, Millipore). The fine particle filter was followed by a nylon backup filter (Pall, Nylasorb, pore size $1.0 \mu \mathrm{m})$ in order to collect nitric acid evaporating from aerosol particles on the upper filter. The VI used the same sampling line as the PILS system, so acidic gases and ammonia were removed also from the sample air entering the VI. The total flow rate of the VI was $16.71 \mathrm{~min}^{-1}$. The sampling duration was $24 \mathrm{~h}$. The PTFE filters were weighed before and after the sampling. After the sampling, the PTFE samples were cut into four pieces and stored frozen at $-20^{\circ} \mathrm{C}$ before chemical analyses.

Anions and cations were analyzed from the PTFE filters by using two Dionex DX500 ion chromatograph systems (Dionex, Sunnyvale, USA). One quarter of the filter was used to extract collected particulate matter using a solution consisting of $10 \% \mathrm{MeOH}$ in deionized water (Milli-Q, Millipore Gradient A10). The anions were analyzed using a $4 \times 250 \mathrm{~mm}$ AS-11 analytical column and $4 \times 50 \mathrm{~mm}$ AG-11 guard column with chemical suppression (sulfuric acid) and $\mathrm{NaOH}$ eluent (gradient run from 0.3 to $16.7 \mathrm{mM}$, runtime $12 \mathrm{~min})$. The cations were analyzed using a $4 \times 250 \mathrm{~mm}$ CS$12 \mathrm{~A}$ analytical column, $4 \times 50 \mathrm{~mm}$ CG-12A guard column, $4 \mathrm{~mm}$ CSRS-ULTRA II suppressor and methanesulfonic acid eluent (isocratic run with $20 \mathrm{mM}$ MSA, runtime $12 \mathrm{~min}$ ). The determined ions were the same as those determined by the PILS-IC system. The uncertainty of IC analysis from the filters was $5-10 \%$ for all of the analyzed ions. Anions from the nylon backup filters were analyzed in a similar way as those from the PTFE filters.

Three monosaccharide anhydrides (levoglucosan, galactosan, mannosan) were determined from one quarter of the VI samples by using a liquid chromatograph mass spectrometer (LC-MS; Agilent 1100 Series, Trap SL, Agilent Technologies, USA). The column used was Atlantis ${ }^{\circledR} \mathrm{dC}_{18} 3 \mu \mathrm{m}$, $2.1 \times 150 \mathrm{~mm}$. The standards for quantitative chemical analysis were prepared by dissolving known amounts of monosaccharide anhydrides with $50 \%$ tetrahydrofurane in deionized water. The VI samples were dissolved with $50 \%$ tetrahydrofurane in deionized water. The uncertainty of the LC-MS method for monosaccharide anhydrides was estimated to be $20 \%$. More details about the LC-MS analyses can be found in Saarikoski et al. (2007).

The trace elements were analyzed by using an inductively coupled plasma mass spectrometer (ICP-MS; Perkin Elmer Sciex Elan 6000, The Perkin-Elmer Corporation, Norwalk, USA) from one quarter of the VI samples. The aerosol sample was extracted with a $\mathrm{HNO}_{3}-\mathrm{HF}$ mixture $(3+1)$ (Jalkanen et al., 1996). Al, As, Cd, Co, Cr, Cu, Fe, Mn, Ni, Pb, Sb, $\mathrm{V}$ and $\mathrm{Zn}$ were analyzed by the ICP-MS. The uncertainty of the ICP-MS analyses was of the order of $25 \%$ for $\mathrm{Cr}, \mathrm{Cu}$ and $\mathrm{Ni}, 30 \%$ for $\mathrm{Zn}, 35 \%$ for $\mathrm{Fe}$ and $20 \%$ for all the other trace elements.

Particle number size distributions were measured with a twin differential mobility particle sizer (DMPS; Winklmayr et al., 1991). The DMPS measured the number of particles 
Table 1. The concentrations of ions $\left(\mu \mathrm{g} \mathrm{m}^{-3}\right)$ in $\mathrm{PM}_{2.5}$ of the VI (virtual impactor) samples. The largest value of each ion is marked in bold.

\begin{tabular}{|c|c|c|c|c|c|c|c|c|c|c|c|}
\hline $\begin{array}{l}\text { Sampling time } \\
\text { UTC start }\end{array}$ & $\begin{array}{l}\text { Sampling time } \\
\text { UTC end }\end{array}$ & $\begin{array}{l}\text { Distance from } \\
\text { Moscow }[\mathrm{km}]\end{array}$ & $\mathrm{Cl}^{-}$ & $\mathrm{NO}_{3}^{-}$ & $\mathrm{SO}_{4}^{2-}$ & $O x^{2-}$ & $\mathrm{Na}+$ & $\mathrm{NH}_{4}^{+}$ & $\mathrm{K}^{+}$ & $\mathrm{Mg}^{2+}$ & $\mathrm{Ca}^{2+}$ \\
\hline 05/10/2005 13:16 & 06/10/2005 10:02 & $1761-3268$ & 0.108 & 0.430 & 1.802 & 0.116 & 0.079 & 0.534 & 0.391 & 0.019 & 0.051 \\
\hline 06/10/2005 16:15 & 07/10/2005 13:26 & $3287-4561$ & 0.058 & 0.180 & 0.988 & 0.082 & 0.061 & 0.259 & 0.175 & 0.012 & 0.089 \\
\hline 07/10/2005 16:22 & 08/10/2005 11:11 & $4751-5884$ & 0.069 & 0.196 & 1.480 & 0.082 & 0.109 & 0.417 & 0.193 & 0.010 & 0.068 \\
\hline 08/10/2005 12:05 & 09/10/2005 09:15 & 5926-7064 & 0.030 & 0.423 & 0.945 & 0.159 & 0.039 & 0.461 & 0.111 & 0.007 & 0.049 \\
\hline 09/10/2005 09:20 & 10/10/2005 09:07 & $7064-8476$ & 0.123 & 0.563 & 0.952 & 0.133 & 0.058 & 0.281 & 0.468 & 0.013 & 0.111 \\
\hline 10/10/2005 09:14 & $10 / 10 / 200522: 05$ & $8476-9242$ & 0.051 & 0.250 & 1.870 & 0.159 & 0.083 & 0.577 & 0.332 & 0.014 & 0.080 \\
\hline 11/10/2005 09:30 & 12/10/2005 09:00 & $7818-9230$ & 0.051 & 0.520 & 10.719 & 0.290 & 0.146 & 3.352 & 0.777 & 0.067 & 0.132 \\
\hline $12 / 10 / 2005$ 09:51 & 13/10/2005 07:39 & $6538-7800$ & 0.003 & 0.103 & 4.085 & 0.092 & 0.035 & 1.325 & 0.233 & 0.015 & 0.029 \\
\hline 13/10/2005 07:46 & 14/10/2005 08:19 & $5136-6538$ & 0.016 & 0.022 & 0.552 & 0.011 & 0.028 & 0.176 & 0.016 & 0.004 & 0.024 \\
\hline $14 / 10 / 200508: 25$ & $15 / 10 / 200514: 38$ & $3286-5136$ & 0.081 & 0.144 & 0.886 & 0.025 & 0.040 & 0.281 & 0.066 & 0.006 & 0.039 \\
\hline $15 / 10 / 200522: 24$ & $16 / 10 / 200510: 18$ & $2376-3286$ & 0.029 & 0.304 & 3.825 & 0.137 & 0.067 & 1.262 & 0.326 & 0.011 & 0.028 \\
\hline $16 / 10 / 200510: 31$ & 17/10/2005 09:20 & $951-2376$ & 0.088 & 0.523 & 4.617 & 0.213 & 0.106 & 1.557 & 0.496 & 0.023 & 0.063 \\
\hline $17 / 10 / 200509: 28$ & 18/10/2005 00:01 & $0-940$ & 0.033 & 0.509 & 4.292 & 0.235 & 0.100 & 1.298 & 0.680 & 0.009 & 0.062 \\
\hline
\end{tabular}

in 50 (+2 zero) partially overlapping voltage channels (for more detailed description of the DMPS used here, see Vartiainen et al., 2007). The DMPS raw data were converted into number size distributions which were further converted into volume size distributions. By integrating the volume distribution between 3 and $950 \mathrm{~nm}$ (electrical mobility diameter of a particle), the total volume concentration of particles for this size range was obtained with a ten-minute time resolution.

\subsection{Other data}

The laboratory carriage was equipped with instruments for measuring meteorological variables (temperature, air pressure, humidity, solar radiation) as well as concentrations of gaseous compounds $\left(\mathrm{O}_{3}, \mathrm{NO}, \mathrm{NO}_{2}, \mathrm{CO}, \mathrm{CO}_{2}, \mathrm{SO}_{2}, \mathrm{CH}_{4}\right.$, $\mathrm{NMHC}$ ). Measurements were also made for the wind speed, wind direction, vertical wind speed and for the concentrations of of ${ }^{222} \mathrm{Rn}$ and its decay products $\left({ }^{218} \mathrm{Po},{ }^{214} \mathrm{~Pb},{ }^{214} \mathrm{Bi}\right)$. The date and time, distance in kilometers from Moscow, latitude, longitude, altitude, as well as the speed and course of the train were recorded during the journey using a GPS.

\section{Results and discussion}

The concentrations of measured chemical components in aerosol particles varied largely during the journey. This was expected, since the railway route included remarkably polluted regions from Moscow to Yekaterinburg and from Khabarovsk to Vladivostok (Fig. 1). In these areas the main aerosol sources are energy production, process industry and traffic. The railway route went also through sparselypopulated regions in mid-Siberia between Novosibirsk and Chita (Fig. 1). In this natural background area, there were major local sources due to forest fires, which could be seen as high temporary concentration levels in the measurements. In this paper, we concentrate on the $\mathrm{PM}_{2.5}$ aerosol fraction.

3.1 Back trajectories and meteorological conditions during the expedition

In order to get some idea on the potential source areas of measured aerosol particles during the journey, 96-h air mass back trajectories were calculated for the arrival heights of 100 and $500 \mathrm{~m}$ above the ground level by using the HYSPLIT-4 model, developed by NOAA/ARL (Draxler and Hess, 1998). The HYSPLIT-4 is a single particle lagrangian trajectory dispersion model. The model runs were made using the Global FNL meteorological archive with a spatial resolution of $190 \times 190 \mathrm{~km}$. The trajectories were calculated every $6 \mathrm{~h}$, such that the location of the arriving air mass at each time corresponded to the location of the train at the same time.

According to the trajectory analysis, the source areas of the sampled air masses were different between the two transects (from Moscow to Vladivostok and from Vladivostok to Moscow) (Fig. 2). In the middle of the route the air came mainly from the south-west direction (direction of Kazakhstan) on the way to Vladivostok and from the northern side of Mongolia on the way back to Moscow. Near Vladivostok the measured air masses came from west (mid-Siberia) on the way to Vladivostok, whereas on the way back to Moscow the air came from south (China). No major differences in air mass transport areas between the trajectories arriving at $100 \mathrm{~m}$ and $500 \mathrm{~m}$ heights were observed, so in the following we use solely the trajectories arriving at the $100 \mathrm{~m}$ height.

The average ambient temperature varied between -5.5 and $22.3^{\circ} \mathrm{C}$ and relative humidity between 24 and $100 \%$ during the expedition. The air pressure varied in the range 
Table 2. The concentrations of total particulate mass, levoglucosan, mannosan and galactosan $\left(\mu \mathrm{g} \mathrm{m}^{-3}\right)$ in PM 2.5 of the VI (virtual impactor) samples, the average concentration of $\mathrm{BC}$ (black carbon) in IR (infrared) and UV (ultraviolet) channels, and total $\mathrm{NO}_{3}^{-}$concentration from the PTFE (teflon) and nylon filters. The largest value of each component is marked in bold.

\begin{tabular}{llllllllll}
\hline $\begin{array}{l}\text { Sampling time } \\
\text { UTC start }\end{array}$ & $\begin{array}{l}\text { Sampling time } \\
\text { UTC end }\end{array}$ & $\begin{array}{l}\text { Distance from } \\
\text { Moscow [km] }\end{array}$ & Mass & $\begin{array}{l}\text { BC } \\
\text { (IR } \\
\text { channel) }\end{array}$ & $\begin{array}{l}\text { BC } \\
\text { (UV } \\
\text { channel) }\end{array}$ & $\begin{array}{l}\text { Galacto } \\
\text { san }\end{array}$ & $\begin{array}{l}\text { Manno } \\
\text { san }\end{array}$ & $\begin{array}{l}\text { Levogl } \\
\text { ucosan }\end{array}$ & $\begin{array}{l}\text { PTFE+nylon } \\
\text { NO }_{3}^{-}\end{array}$ \\
\hline 05/10/2005 13:16 & $06 / 10 / 200510: 02$ & $1761-3268$ & 24.24 & 6.15 & 6.49 & 0.039 & 0.011 & 0.204 & 1.00 \\
06/10/2005 16:15 & $07 / 10 / 200513: 26$ & $3287-4561$ & 20.22 & 5.90 & 5.89 & 0.029 & 0.017 & 0.202 & 0.45 \\
$07 / 10 / 200516: 22$ & $08 / 10 / 200511: 11$ & $4751-5884$ & 18.19 & 7.20 & 6.72 & 0.030 & 0.018 & 0.157 & 0.52 \\
08/10/2005 12:05 & $09 / 10 / 200509: 15$ & $5926-7064$ & $\mathbf{3 4 . 8 0}$ & 5.44 & 6.55 & $\mathbf{0 . 2 6 5}$ & $\mathbf{0 . 1 5 3}$ & $\mathbf{0 . 9 5 8}$ & 0.87 \\
09/10/2005 09:20 & $10 / 10 / 200509: 07$ & $7064-8476$ & 23.80 & 5.29 & 6.14 & 0.068 & 0.022 & 0.241 & 0.96 \\
$10 / 10 / 200509: 14$ & $10 / 10 / 200522: 05$ & $8476-9242$ & 16.86 & 5.01 & 4.58 & 0.020 & 0.007 & 0.073 & 0.40 \\
$11 / 10 / 200509: 30$ & $12 / 10 / 200509: 00$ & $7818-9230$ & 31.98 & 6.47 & 5.77 & 0.015 & 0.006 & 0.089 & 1.79 \\
$12 / 10 / 200509: 51$ & $13 / 10 / 200507: 39$ & $6538-7800$ & 14.45 & 2.28 & 2.08 & 0.032 & 0.013 & 0.130 & 1.15 \\
$13 / 10 / 200507: 46$ & $14 / 10 / 200508: 19$ & $5136-6538$ & 4.30 & 2.09 & 1.83 & 0.003 & 0.002 & 0.011 & 0.07 \\
$14 / 10 / 200508: 25$ & $15 / 10 / 200514: 38$ & $3286-5136$ & 10.33 & 3.90 & 3.76 & 0.019 & 0.010 & 0.143 & 0.29 \\
$15 / 10 / 200522: 24$ & $16 / 10 / 200510: 18$ & $2376-3286$ & 24.23 & 5.74 & 5.36 & 0.027 & 0.008 & 0.165 & 1.29 \\
$16 / 10 / 200510: 31$ & $17 / 10 / 200509: 20$ & $951-2376$ & 32.94 & $\mathbf{9 . 7 7}$ & $\mathbf{9 . 7 4}$ & 0.058 & 0.031 & 0.449 & $\mathbf{2 . 1 2}$ \\
$17 / 10 / 200509: 28$ & $18 / 10 / 200500: 01$ & $0-940$ & 24.13 & 5.25 & 5.22 & 0.031 & 0.019 & 0.235 & 1.55 \\
\hline
\end{tabular}

896-1025 mbar. The overall weather conditions were cooler and cloudier on the way from Vladivostok to Moscow than on the way from Moscow to Vladivostok. Snowfall was encountered around $5700 \mathrm{~km}$ east of Moscow on the morning of 14 October (Vartiainen et al., 2007).

\subsection{Particulate mass concentrations}

The mass concentrations of $\mathrm{PM}_{2.5}$ from the VI samples varied in the range $4.3-34.8 \mu \mathrm{g} \mathrm{m}^{-3}$, the average concentration being $21.6 \mu \mathrm{g} \mathrm{m}^{-3}$. The measured $\mathrm{PM}_{2.5}$ mass concentrations were, in general, similar to those measured at urban background sites in Europe (Querol et al., 2004) and urban areas in United States (Pinto et al., 2004). In one region in mid-Siberia on the way back to Moscow, the measured $\mathrm{PM}_{2.5}$ mass concentration was lower than what has been reported for regional background sites in Europe (Querol et al., 2004). The mass concentrations measured in this work were substantially lower than concentrations measured in six Asian cities (Kim Oanh et al., 2006) during the dry season (44-168 $\left.\mu \mathrm{g} \mathrm{m}^{-3}\right)$, or during most of the wet season (18$\left.104 \mu \mathrm{g} \mathrm{m}^{-3}\right)$.

The $\mathrm{PM}_{2.5}$ mass concentrations obtained from the VI measurement were compared with particle volume concentrations obtained from the DMPS measurements. In order to do this, we averaged the DMPS data over each VI sampling. There was a high correlation between the mass and volume concentrations $\left(\mathrm{R}^{2}=0.92\right.$, Fig. 3 ). The average density of aerosol particles during the campaign can be estimated from the slope of the regression line, and it was $1.76 \mathrm{~g} \mathrm{~cm}^{-3}$. The density varied between 1.5 and $2.4 \mathrm{~g} \mathrm{~cm}^{-3}$
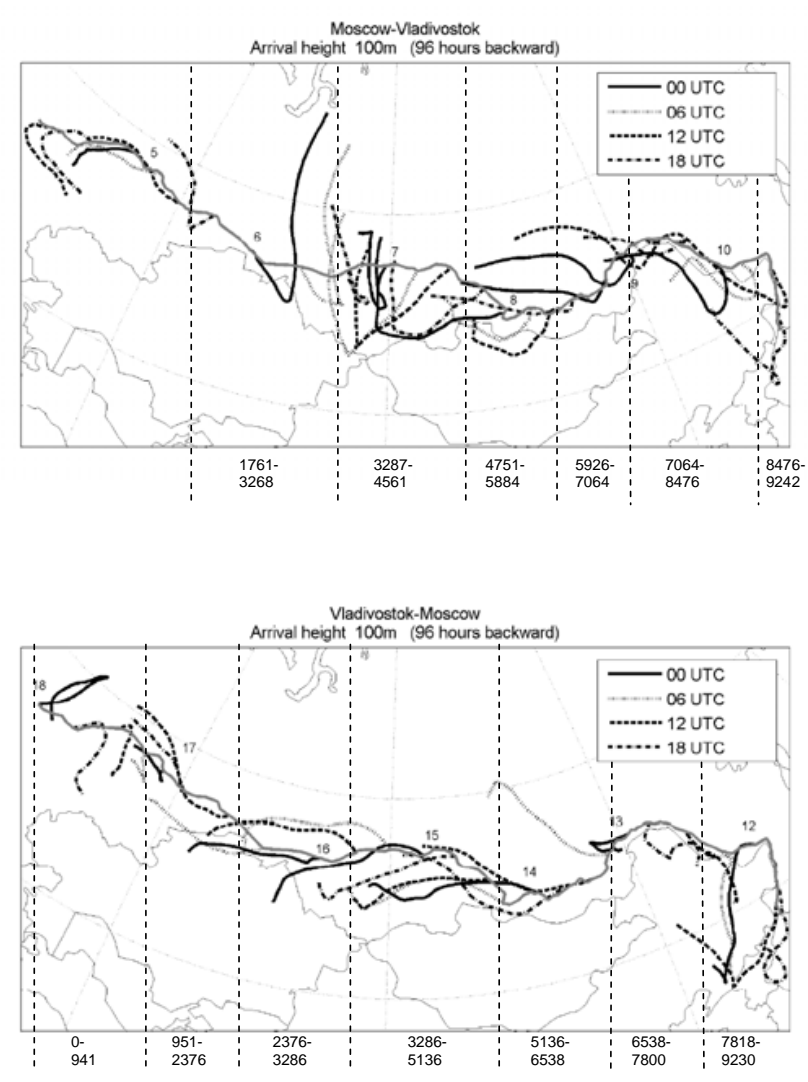

Fig. 2. 96-h backward air mass trajectories for the arrival height of $100 \mathrm{~m}$ during the expedition. 


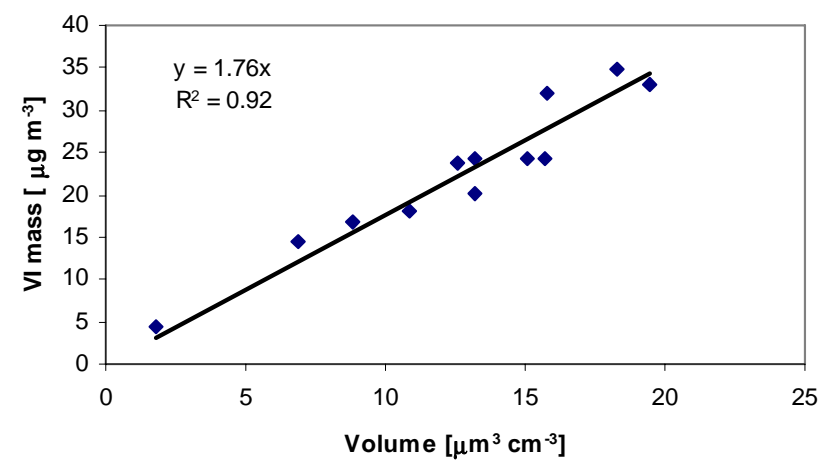

Fig. 3. The relation between average volume $\left(\mu \mathrm{m}^{3} \mathrm{~cm}^{-3}\right)$ and mass $\left(\mu \mathrm{g} \mathrm{m}^{-3}\right)$ concentrations during the campaign.

during the campaign, being higher close to Vladivostok and lower near Moscow. The density obtained by the similar way from DMPS measurements and gravimetric mass of VI samples for fine particles was $1.66 \pm 0.13 \mathrm{~g} \mathrm{~cm}^{-3}$ in May 2004 in a background area of southern Finland (Saarikoski et al., 2005).

\subsection{Chemical composition of $\mathrm{PM}_{2.5}$}

The concentrations of the measured ions and total mass as well as the concentrations of levoglucosan, galactosan and mannosan, are shown in Tables 1 and 2. The BC concentration from the aethalometer measurements was averaged over each VI sampling period (Table 2). Concentrations of most of the ions and $\mathrm{BC}$ were low in mid-Siberia, whereas higher concentrations were observed near Moscow and Vladivostok. The different concentration levels between the urban and rural areas could be seen more clearly on the way back to Moscow than on the way to Vladivostok. The particle mass concentration followed closely the concentrations of major ions, except in one sample collected in mid-Siberia on the way to Vladivostok. This sample, discussed later in more detailed, was affected by forest fires and showed an elevated particle mass concentration without a similar increase in ion concentrations.

The levoglucosan concentration, a tracer of incomplete biomass combustion (Simoneit et al., 1999), varied typically between 0.01 and $0.45 \mu \mathrm{g} \mathrm{m}^{-3}$, but in one sample (5926$7064 \mathrm{~km}$ from Moscow) on the way to Vladivostok it reached a value of $0.96 \mu \mathrm{g} \mathrm{m}^{-3}$ (Table 2). The particle mass concentration was the highest for this sample. However, compared with other samples, the ion and BC concentrations did not increase similar to the levoglucosan concentration. This shows indirectly that in this sample most of the aerosol mass consisted of particulate organic matter. The high contribution of particulate organic matter is most probably due to biomass burning, as has been observed also elsewhere during forest fire episodes (e.g. Saarikoski et al., 2007). In the area having the high levoglucosan concentration, the aethalometer UV channel showed sustained increases over the IR channel concentration, which is probably due to organic compounds absorbing the UV radiation (Table 2).

The concentrations of the trace elements from the VI samples in $\mathrm{PM}_{2.5}$ are shown in Fig. 4. The VI sample corresponding to the distance of 951-2376 km from Moscow (on the way from Vladivostok to Moscow) was collected when the train passed through the big cities of Yekaterinburg and Perm. In this sample the concentrations of $\mathrm{Pb}, \mathrm{Zn}, \mathrm{As}, \mathrm{V}$ and $\mathrm{Cd}$ were at their highest level. In the same area also the concentrations of $\mathrm{BC}$ were at their highest. Traffic and different industrial processes can be sources of these compounds in the vicinity of big cities. The same compounds had high concentration on the way to Vladivostok, but since the measurements started after Perm, the VI sample 1761-3268 km from Moscow included only the passage through Yekaterinburg. In the VI samples close to Vladivostok, the concentrations of soil-derived elements $\mathrm{Al}, \mathrm{Ca}, \mathrm{Fe}$ and $\mathrm{Mn}$ (Song et al., 2001) were elevated both when going to Vladivostok and when coming back to Moscow. The concentrations of $\mathrm{Cr}$ and $\mathrm{Ni}$ were elevated near Vladivostok only on the way there, but not when coming back to Moscow. This indicates that their sources were more likely regional or long-range transport than local. $\mathrm{Cr}$ and $\mathrm{Ni}$ can be emitted from coal or oil combustion (NAEI 2003).

A summary of the mean mass concentrations in $\mathrm{PM}_{2.5}$ and chemical components in it between Moscow and Vladivostok is shown in Fig. 5. The mass concentrations were taken from the VI samples, except that of $\mathrm{BC}$ which was taken from the aethalometer measurements. The contributions of measured chemical compounds to fine particles for each VI sample are shown in Fig. 6. Fine particles consisted mainly of BC (15.8$48.7 \%$, average $27.6 \%), \mathrm{SO}_{4}^{2-}(2.7-33.5 \%, 13.0 \%), \mathrm{NH}_{4}^{+}$ $(1.2-10.5 \%, 4.1 \%)$, and $\mathrm{NO}_{3}^{-}(0.5-2.4 \%, 1.4 \%)$. Trace metals together accounted for $0.4-9.8 \%$ of the fine particulate mass. The fraction of monosaccharide anhydrides was in the range 0.4-1.6\%, except in one sample (5926-7064 km from Moscow) on the way to Vladivostok when it was as high as $4 \%$. The measured chemical components accounted for $27.7-78.5 \%$ of the $\mathrm{PM}_{2.5}$ mass. The unidentified fraction is expected to include organic particulate matter, waterinsoluble material and water. The concentration of waterinsoluble inorganic matter, calculated based on measured aluminum concentrations, was found to be typically less than $10 \%$ in the collected samples. The unidentified fraction was highest in the sample having the highest total aerosol mass and levoglucosan concentration. As mentioned above, most of the unidentified mass in this sample was probably organic particulate matter formed in forest fires. Close to wildfires or biomass burning, organic material can account for up to $70-90 \%$ of the total aerosol mass (Yamasoe et al., 2000).

The contribution of $\mathrm{BC}$ to $\mathrm{PM}_{2.5}$ was much higher during the whole expedition than what has been observed in Europe, 

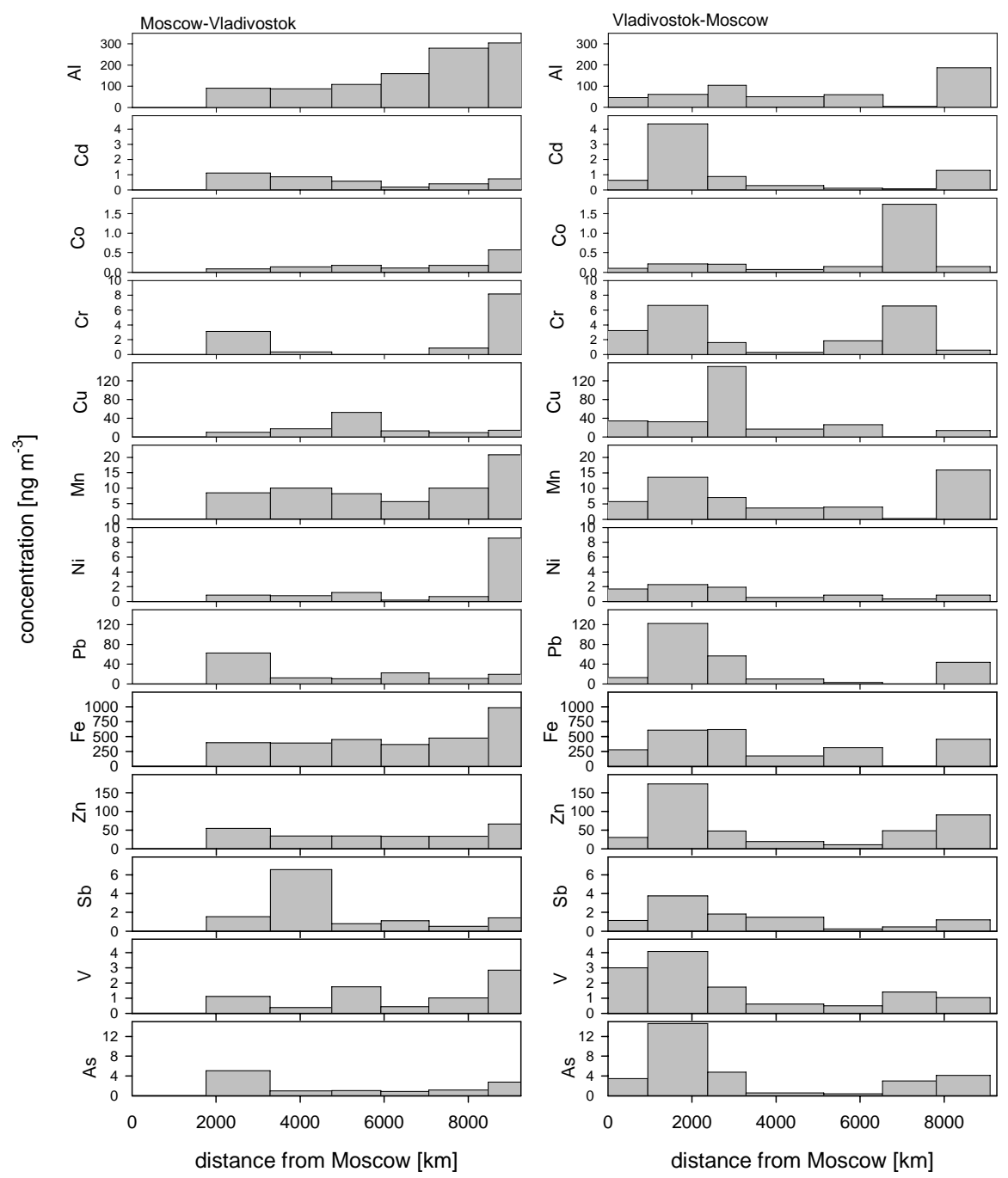

Fig. 4. The concentrations of the trace elements $\left(n \mathrm{~m} \mathrm{~m}^{-3}\right)$ in $\mathrm{PM}_{2.5}$.

where the $\mathrm{BC}$ fraction has estimated to be in the range $5-10 \%$ (Putaud et al., 2004). The fraction of EC (elemental carbon) in $\mathrm{PM}_{2.5}$ has been found to be $5.4-9.0 \%$ in urban areas in Europe (Sillanpää et al., 2006). In China, the contribution of EC to $\mathrm{PM}_{2.5}$ has been estimated to be $6.6-8.8 \%$ (Cao et al., 2004). Measurements made by Sillanpää et al. (2006) at six urban sites in Europe showed nss- $\mathrm{SO}_{4}^{2-}$ concentrations of $14-31 \%$ to $\mathrm{PM}_{2.5}$. During our expedition the $\mathrm{SO}_{4}^{2-}$ contribution was lower on the way to Vladivostok, but on the way to Moscow it was close to contributions measured in Europe. The contributions of $\mathrm{NO}_{3}^{-}$and $\mathrm{NH}_{4}^{+}$to $\mathrm{PM}_{2.5}$ in Europe have been found to be in the ranges $1.1-18 \%$ and 7.0 9.3\% (Sillanpää et al., 2006), respectively, which are higher values than measured during our expedition.
3.4 Variability of concentrations during the campaign

In order to get information on rapidly changing concentrations of ions in aerosol particles, PILS measurements were made during the journey. The 15 -min time resolution of the PILS gives much better information on the changing aerosol ion composition than the VI which integrated the sampling over more than a thousand of kilometers. Ion concentrations from PILS measurements are typically lower than concentrations based on filter or impactor measurements (Orsini et al., 2003). The typical concentration ratios between the PILS and impactor measurements have been of the order of $0.7-0.9$ for major ions like $\mathrm{SO}_{4}^{2-}, \mathrm{NO}_{3}^{-}$and $\mathrm{NH}_{4}^{+}$(Ma et al., 2004). The correlations between the concentrations measured by the PILS and impactor have usually been relatively high (Ma et al., 2004). 

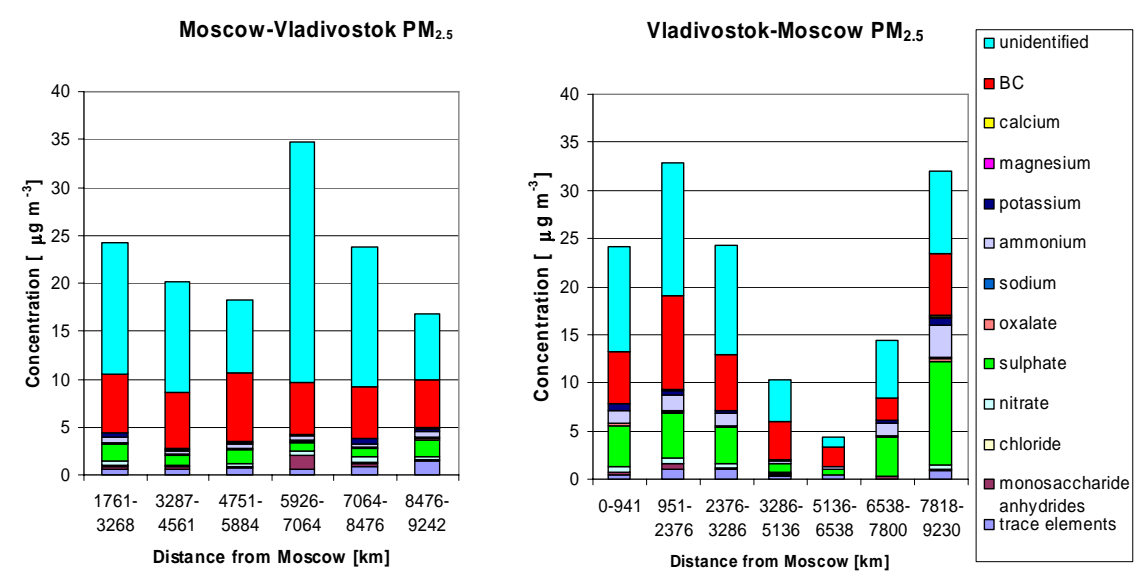

Fig. 5. The mass concentrations of ions, BC, monosaccharide anhydrides, trace elements and unidentified matter in $\mathrm{PM}_{2.5}$ between $\mathrm{Moscow}$ and Vladivostok.
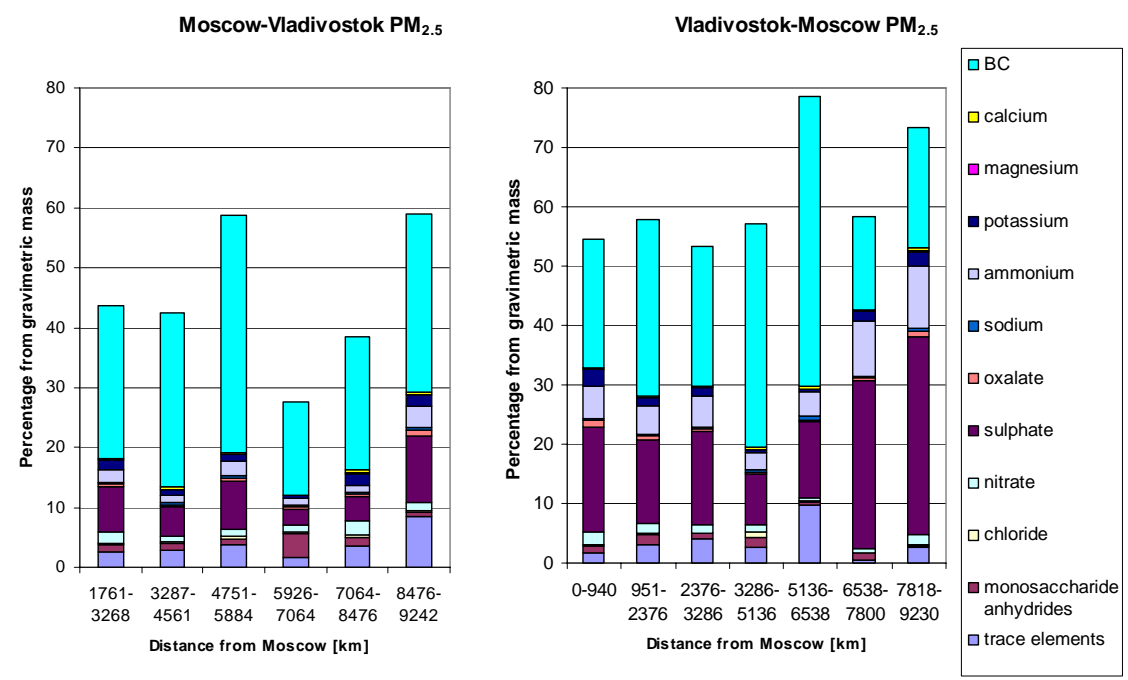

Fig. 6. The contributions of ions, BC, monosaccharide anhydrides, trace elements and unidentified matter to $\mathrm{PM}_{2.5}$ between Moscow and Vladivostok.

It seems that there were some problems with the PILS measurements during the expedition. The concentration ratios of measured ions between the PILS and VI were unusually low, and the agreement being good only for sulphate $\left(R^{2}=0.68\right)$ and ammonium $\left(R^{2}=0.75\right)$. The correlations between VI concentrations and average PILS concentrations during the sampling time for $\mathrm{SO}_{4}^{2-}$ and $\mathrm{NH}_{4}^{+}$are shown in Fig. 7. The uncertainties in the PILS measurements can be due to uncertainties in the IC analyses connected with the PILS system, in sample or liquid flow rates, or in particle losses inside the sampling system. The sample flow rate was monitored during the expedition and losses for particles smaller than $2.5 \mu \mathrm{m}$ of aerodynamic diameter should have been minimal. The accuracies of the IC systems were checked with standard test solutions. The most probable explanation for the lower concentrations measured with the PILS system was either problems with the liquid flow rates of the system or some unexpected problems caused by strong vibrations in the moving train. The concentrations of potassium, oxalate, sodium, chloride, calcium and magnesium were near the detection limit of the PILS system, which might further explain the observed differences.

The concentration differences between the VI and PILS measurements were unexpectedly large for nitrate, although the measured nitrate concentrations were most of the time clearly above the detection limit. In some occasions nitrate concentrations measured with the PILS were much higher than those measured with the VI. When having a more 
detailed look at the VI and PILS results, it seems that evaporation of nitrate from the PTFE filters had been taking place during the samplings. Large amounts of nitrate were found in the nylon backup filters, as well as small amounts of chloride. Sometimes the nitrate concentrations in the nylon filters were higher than those in the PTFE filters. When comparing the nitrate concentration obtained from the PILS with the sum of nitrate found in the PTFE and nylon filters (Table 2), the agreement between these two measurement devices was much better. The calculated average cation to anion ratio (PTFE) was 0.98 and varied from 0.91 to 1.07 . This ratio is related to the acidity of aerosol particles and was near unity here. It is possible that particulate ammonium nitrate and ammonium chloride evaporated as volatile acids like nitric acid and hydrochloridic acid from the PTFE filter during the sampling. Since denuders were used upstream of the sampling line, the extent of evaporation from the PTFE filters may have increased. Such evaporation is taking place until equilibrium between the cations and anions is being reached (neutralization). When looking at the VI sample between 7818-9230 $\mathrm{km}$ on the way back to Moscow, much higher nitrate concentrations were obtained from the PILS measurements than from the VI PTFE filter. In this sample also the amount of nitrate found in the nylon backup filter was the highest. The high concentration of sulphate in this same sample indicates that the collected aerosol was very acidic, which had probably increased the evaporation of nitrate from the PTFE filter. Although the concentrations from the PILS measurements were lower than those from the VI measurements, they still give valuable information on the variability of the ion concentrations during the journey because of the high temporal resolution of these measurements. From the PILS data it is also possible to find temporary high concentration levels and exact locations of the events such as forest fires. The PILS data were used in this study merely to see fast temporal variations in ion concentrations.

The concentrations of $\mathrm{SO}_{4}^{2-}, \mathrm{NO}_{3}^{-}$and $\mathrm{NH}_{4}^{+}$from the PILS measurements $\left(\mathrm{D}_{p}<2.5 \mu \mathrm{m}\right), \mathrm{BC}$ from the aethalometer and volume concentration of particles $\left(\mu \mathrm{m}^{3} \mathrm{~cm}^{-3}\right)$ from DMPS measurements are shown in Fig. 8. On the way to Vladivostok the measured concentrations did not show a very large variability. On the way back to Moscow, clear differences between the background areas in mid-Siberia (4000$7200 \mathrm{~km}$ from Moscow) and urban areas could be seen. Also several temporary high concentration levels could be identified from the PILS data. Some of these peaks were due to passings through industrial areas during the journey. Especially in the beginning of the way back to Moscow (7400$8800 \mathrm{~km}$ from Moscow), the concentration of $\mathrm{SO}_{4}^{2-}, \mathrm{NO}_{3}^{-}$, $\mathrm{NH}_{4}^{+}$and $\mathrm{BC}$, as well as the total particle volume concentration were high.
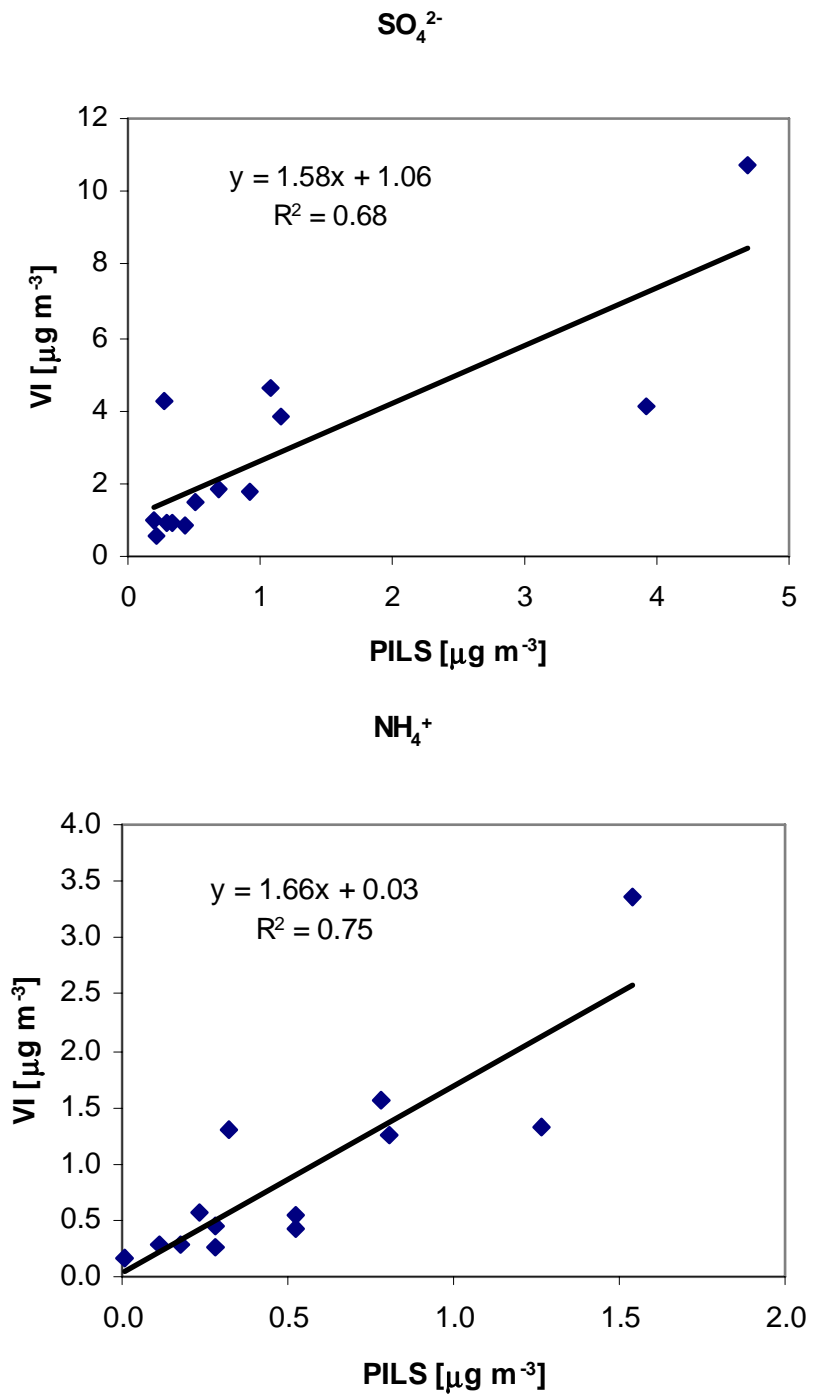

Fig. 7. Comparison of $\mathrm{SO}_{4}^{2-}$ and $\mathrm{NH}_{4}^{+}$concentrations obtained from VI samplings and PILS measurements.

\subsection{Selected regions}

\subsubsection{A high-concentration region}

On the way back to Moscow, concentrations of ions, BC and particle volume were at a high level over large distances (7400-8800 km from Moscow). The concentrations of $\mathrm{SO}_{4}^{2-}, \mathrm{NO}_{3}^{-}$and $\mathrm{NH}_{4}^{+}$were around one order of magnitude higher on the way to back to Moscow than on the way to Vladivostok. The concentrations of BC and particle volume were quite similar during both directions in this area, but high compared with concentrations measured during the whole expedition. From the calculated air mass back trajectories it can be seen that on the way back to Moscow, the ion concentrations were high for air masses traveled through 


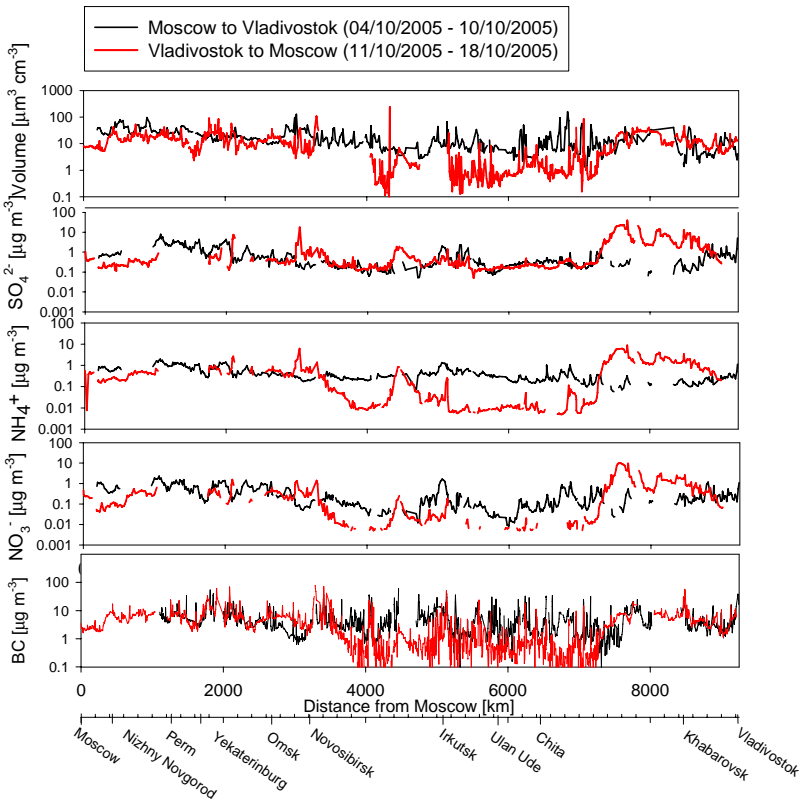

Fig. 8. The concentrations of sulphate, nitrate, ammonium, BC $(\mu \mathrm{g}$ $\left.\mathrm{m}^{-3}\right)$ and total particle volume $\left(\mu \mathrm{m}^{3} \mathrm{~cm}^{-3}\right)$ between Moscow and Vladivostok.

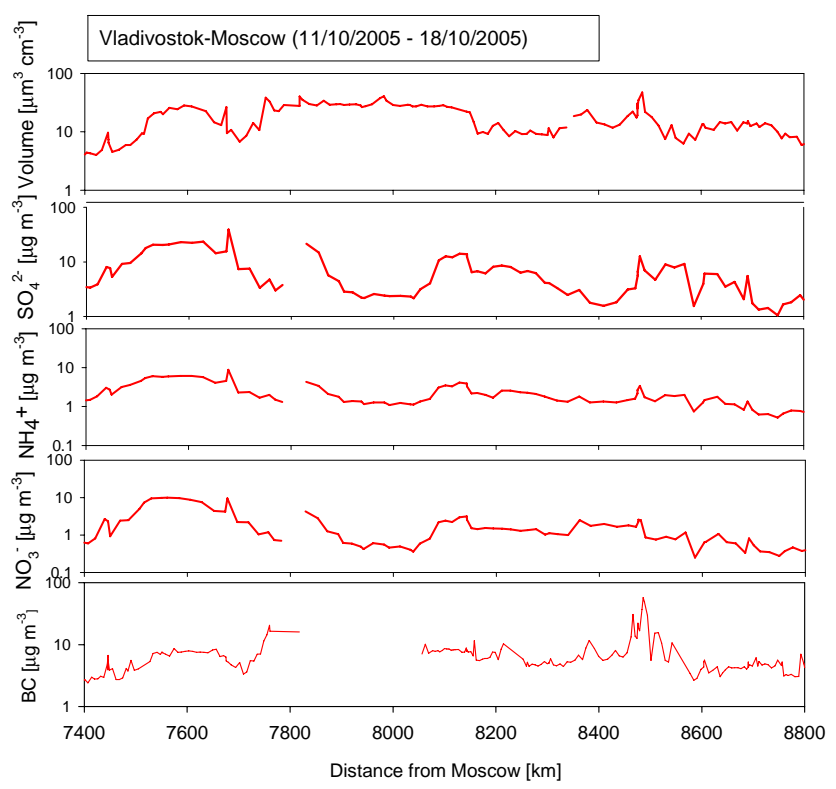

Fig. 9. The concentrations of sulphate, nitrate, ammonium, $B C$ $\left(\mu \mathrm{g} \mathrm{m}^{-3}\right)$ and total particle volume $\left(\mu \mathrm{m}^{3} \mathrm{~cm}^{-3}\right)$ in the highconcentration region.

the north-east China. When the source area of the air masses was close to the Russian border on the way to Vladivostok, the concentrations of ions were not as high.

It is quite evident that the measured high concentrations on the way back to Moscow were mostly long- range-transported aerosol particles. The increased potassium and oxalate concentrations in this area are indicative of biomass burning. The presence of calcium is an indicator of long-range-transported soil particles. The concentrations of $\mathrm{SO}_{4}^{2-}, \mathrm{NO}_{3}^{-}$and $\mathrm{NH}_{4}^{+}$from the PILS measurements $\left(\mathrm{D}_{p}<2.5 \mu \mathrm{m}\right)$ and $\mathrm{BC}$ from the aethalometer measurements, as well as the concentration of particles $\left(\mu \mathrm{m}^{3} \mathrm{~cm}^{-3}\right)$ from the DMPS measurements, in this region are shown in Fig. 9. The concentrations of $\mathrm{SO}_{4}^{2-}, \mathrm{NO}_{3}^{-}$and $\mathrm{NH}_{4}^{+}$correlated strongly with each other $\left(\mathrm{R}^{2}=0.95\right.$ between $\mathrm{SO}_{4}^{2-}$ and $\mathrm{NH}_{4}^{+}$; $\mathrm{R}^{2}=0.80$ between $\mathrm{SO}_{4}^{2-}$ and $\mathrm{NO}_{3}^{-} ; \mathrm{R}^{2}=0.88$ between $\mathrm{NO}_{3}^{-}$ and $\mathrm{NH}_{4}^{+}$) (http://www.atmos-chem-phys.net/7/4793/2007/ acp-7-4793-2007-supplement.pdf). The concentrations of $\mathrm{BC}$ and total particles volume varied in the same way but had no correlation with ion concentrations. The concentrations of both $\mathrm{SO}_{4}^{2-}$ and BC were above $1 \mu \mathrm{g} \mathrm{m}^{-3}$ throughout the region, that of $\mathrm{NH}_{4}^{+}$was mainly above $1 \mu \mathrm{g} \mathrm{m}^{-3}$, and that of $\mathrm{NO}_{3}^{-}$was mostly below $1 \mu \mathrm{g} \mathrm{m}^{-3}$. The total particle volume concentration was most of the time above $10 \mu \mathrm{m}^{3} \mathrm{~cm}^{-3}$.

\subsubsection{A low-concentration region}

The lowest ion concentrations were measured in mid-Siberia (4000-7200 km from Moscow) on the way back to Moscow. This is a rural area with few local pollution sources. In addition to ions, also the concentrations of $\mathrm{BC}$ and particle volume were very low in this area. However, the concentrations of $\mathrm{NO}_{3}^{-}, \mathrm{NH}_{4}^{+}$, $\mathrm{BC}$ and particle volume were around one order of magnitude higher on the way to Vladivostok than on the way back to Moscow. The concentration of sulphate was nearly at the same level during both directions. There was a clear difference in the origin of the air masses between the way to Vladivostok and back to Moscow. It seems that when the air masses were coming from over the northern side of the railroad in mid-Siberia, the air was much cleaner than air coming from the west, southern Russia or near the border of Kazakhstan.

The concentrations of $\mathrm{SO}_{4}^{2-}, \mathrm{NO}_{3}^{-}$and $\mathrm{NH}_{4}^{+}$from the PILS measurements $\left(\mathrm{D}_{p}<2.5 \mu \mathrm{m}\right), \mathrm{BC}$ concentration from the aethalometer measurements, and the total particle volume concentration from the DMPS measurements in the low-concentration region are shown in Fig. 10. In this region, $\mathrm{SO}_{4}^{2-}, \mathrm{NO}_{3}^{-}$and $\mathrm{NH}_{4}^{+}$concentrations correlated well with each other $\left(\mathrm{R}^{2}=0.81\right.$ between $\mathrm{SO}_{4}^{2-}$ and $\mathrm{NH}_{4}^{+}$; $\mathrm{R}^{2}=0.69$ between $\mathrm{SO}_{4}^{2-}$ and $\mathrm{NO}_{3}^{-} ; \mathrm{R}^{2}=0.71$ between $\mathrm{NO}_{3}^{-}$ and $\mathrm{NH}_{4}^{+}$) (http://www.atmos-chem-phys.net/7/4793/2007/ acp-7-4793-2007-supplement.pdf), but not as strongly as in the high-concentration region. The concentrations of $\mathrm{BC}$ and total particles volume varied in the same way but had no correlation with ion concentrations. The observed correlations between the major components reflect their different source types in this region: while the concentration of $\mathrm{BC}$ was very possible influenced by intermitted local sources, the concentration of $\mathrm{SO}_{4}^{2-}$ varied smoothly over larger regional scales. 
Overall, the concentration of $\mathrm{SO}_{4}^{2-}$ was mainly below $1 \mu \mathrm{g} \mathrm{m}^{-3}$ in the low concentration region and that of $\mathrm{NH}_{4}^{+}$ was all the time below $1 \mu \mathrm{g} \mathrm{m}^{-3}$. The $\mathrm{NO}_{3}^{-}$concentration was slightly lower than that of $\mathrm{NH}_{4}^{+}$. The concentration of BC varied between 0.01 and $100 \mu \mathrm{g} \mathrm{m}^{-3}$, while that of total particle volume varied mostly between 0.1 and $10 \mu \mathrm{m}^{3} \mathrm{~cm}^{-3}$. The concentrations of $\mathrm{SO}_{4}^{2-}, \mathrm{NO}_{3}^{-}$and $\mathrm{NH}_{4}^{+}$ were typically one to two orders of magnitude lower in this region as compared with the high-concentration region.

\subsubsection{Forest fire episodes}

On the way to Vladivostok, between $5925-7064 \mathrm{~km}$ from Moscow, the concentration of levoglucosan was extremely high in the VI sample. At the same area, there were three periods with high concentration levels of oxalate and potassium in the PILS measurements (Fig. 11). Oxalate and potassium together with levoglucosan have been used as biomass combustion tracers (Simoneit et al., 1999). Of these, the only specific tracer for biomass combustion is levoglucosan formed during the thermal breakdown of cellulose (Fraser and Lakshmanan, 2000). In addition to biomass combustion, potassium can be derived from soil, whereas oxalate can be formed in the atmosphere from hydrocarbons or be emitted by other primary sources. Different types of man-made or wildfires (e.g. forest fires, agricultural waste combustion, flaming, smoldering) have different emission profiles (Conny and Slater, 2002), in addition to which the chemical composition of emitted particles may be changed during their transportation in the atmosphere.

In a wildfire map based on the observations by the MODIS satellite (http://modis.gsfc.nasa.gov/), forest fires were observed over large areas close to the locations having high concentrations of oxalate and potassium. The concentrations of BC, sulphate and total particle volume were elevated at the same time with biomass combustion tracers, but to very different extents (Fig. 11). The overall concentration of $\mathrm{SO}_{4}^{2-}$ in this region was similar to that in the low-concentration region, with slightly elevated concentrations (up to about $0.5-$ $1 \mu \mathrm{g} \mathrm{m}^{-3}$ ) seen during the forest fire episodes. These $\mathrm{SO}_{4}^{2-}$ concentrations remained, however, clearly below those measured throughout the high-concentration region. Occasionally observed high concentration levels of potassium, black carbon, sulphate and particle volume did not coincide with the high oxalate concentrations. These differences in the composition of biomass combustion particles may be due to differences in burning conditions. Both BC and potassium are emitted to a larger extent from flaming fires compared with smoldering fires, whereas oxalate is emitted preferably from smoldering fires (Iinuma et al., 2007; Allen and Miguel, 1995).

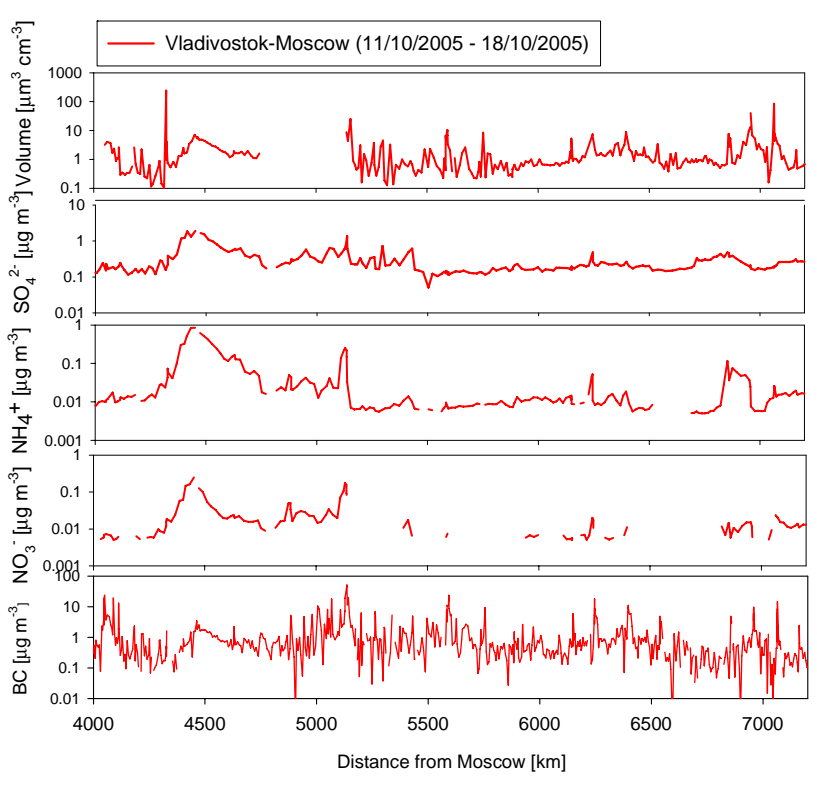

Fig. 10. The concentrations of sulphate, nitrate, ammonium, BC $\left(\mu \mathrm{g} \mathrm{m}^{-3}\right)$ and the total particle volume $\left(\mu \mathrm{m}^{3} \mathrm{~cm}^{-3}\right)$ in the lowconcentration region.

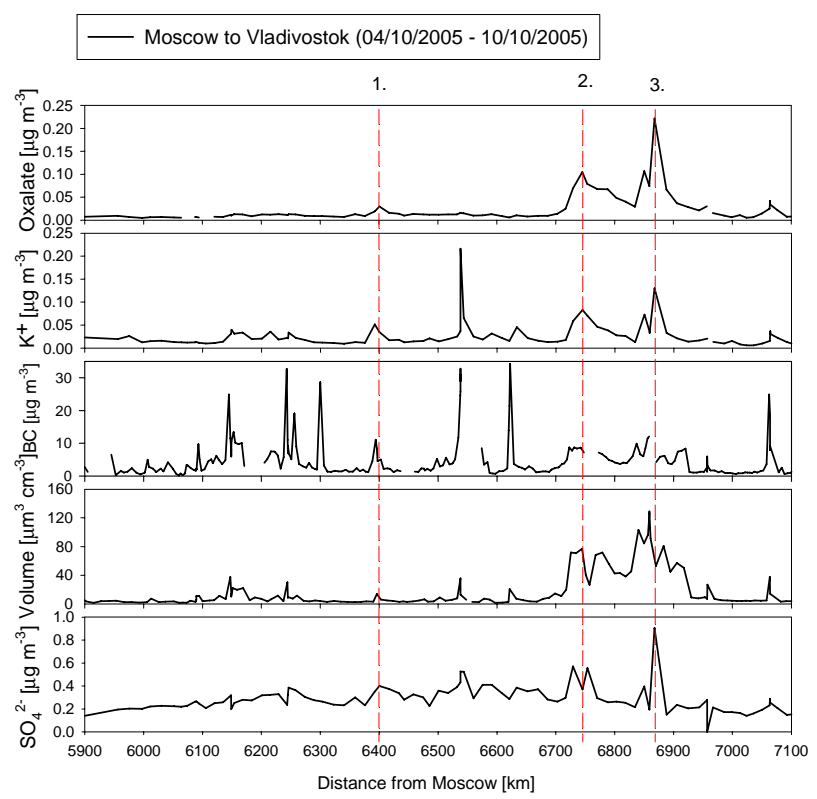

Fig. 11. The concentrations of oxalate, $\mathrm{K}^{+}$, sulphate, $\mathrm{BC}\left(\mu \mathrm{g} \mathrm{m}^{-3}\right)$ and total particle volume $\left(\mu \mathrm{m}^{3} \mathrm{~cm}^{-3}\right)$ in the area where the levoglucosan concentration was high $(5926-7064 \mathrm{~km}$ distance from Moscow) and forest fires were observed.

\section{Summary and conclusions}

Aerosol chemical and physical measurements were made at the Trans-Siberian railway in Russia in October 2005. Concentrations of $\mathrm{BC}$, aerosol ions and particle volume were 
measured using continuously-measuring devices for fine particles $(<2.5 \mu \mathrm{m}$ diameter). In addition, 24-h samples were collected using a virtual impactor for mass concentration determination and chemical analysis.

The concentrations of measured chemical components in aerosol particles varied largely during the journey. Due primarily to local anthropogenic sources, the areas around the route of the Trans-Siberian railway were heavily polluted between Moscow and roughly $4000 \mathrm{~km}$ east of it, as well as in the eastern part of the route close to Vladivostok. Observed concentrations were typically low in the middle of the route, even though there were local particle sources, such as forest fires, that increased particulate matter concentrations occasionally. The polluted air masses from Asia seem to have significant influences on the concentration levels of fine particles over the south-eastern Russia.

The mass concentrations of $\mathrm{PM}_{2.5}$ from the VI samples varied in the range $4.3-34.8 \mu \mathrm{g} \mathrm{m}^{-3}$ with an average of $21.6 \mu \mathrm{g} \mathrm{m}^{-3}$. These concentrations are comparable to those observed in Europe and North America, but considerably lower than concentrations measured in major Asian cities. Fine particles consisted mainly of $\mathrm{BC}$ (average 27.6\%), $\mathrm{SO}_{4}^{2-}(13.0 \%), \mathrm{NH}_{4}^{+}(4.1 \%)$ and $\mathrm{NO}_{3}^{-}(1.4 \%)$. Trace metals together accounted for $0.4-9.8 \%$ of the fine particulate mass. The mass fraction of monosaccharide anhydrides in $\mathrm{PM}_{2.5}$ was in the range $0.4-1.6 \%$, except in one sample (5926$7064 \mathrm{~km}$ from Moscow) collected on the way to Vladivostok, for which it was substantially elevated (4\%) indicative of forest fire emissions. The measured chemical components accounted for $27.7-78.5 \%$ of the $\mathrm{PM}_{2.5}$ mass. The remaining fraction consisted very likely of organic particulate matter and some water, not quantified in our chemical analyses. The contribution of $\mathrm{BC}$ to $\mathrm{PM}_{2.5}$ was much higher than the typical values measured in Europe and Asia.

On the way back to Moscow, the concentrations of ions, $\mathrm{BC}$ and particle volume were at high levels over large distances (7400-8800 km from Moscow). The high concentrations were mainly due to long-range-transported aerosol particles from China. The lowest ion concentrations were measured in mid-Siberia (4000-7200 km from Moscow) on the way back to Moscow. This is a rural area with few local pollution sources. In addition to ions, the concentrations of $\mathrm{BC}$ and particle volume were at low levels in this area. On the way to Vladivostok (5925-7064 km from Moscow), the concentration of levoglucosan was extremely high. In the same region, there were occasions with simultaneous high concentration levels of oxalate, potassium and BC. In a wildfire map based on the observations by the MODIS satellite, there were forest fires over large areas close to the locations with high concentration levels of oxalate, potassium and BC.

Since we used a moving laboratory, measurements with a high time resolution gave more valuable information about the variability of concentrations during the journey than the traditional filter-based sampling methods. From on-line measurements it was possible to identify specific particle sources, including forest fires or industrial areas, which were not detectable from the 24-h VI samples. We also found evidence that evaporation of nitrate from the PTFE filters had been taking place during the samplings. The concentration of nitrate was higher in the high-time-resolution measurements compared with the VI measurements, and large amounts of nitrate were found in the nylon backup filters. The evaporation particulate nitrate seemed to be strongest in the sample having the highest concentration of sulphate, which is expected because the aerosol acidity increases evaporation. The extent of nitrate evaporation may have been enhanced because of the use of denuders upstream of the sampling line.

Acknowledgements. This study was funded by the Academy of Finland (Program "Russia in Flux"), grant no. 208208. The TROICA expedition was partly funded by the ISTC Project \#2773. L. Sogacheva is acknowledged for the trajectory runs.

Edited by: A. Pszenny

\section{References}

Allen, G. A. and Miguel, A. H.: Biomass burning in the Amazon: Characterization of the ionic component of aerosols generated from flaming and smouldering rainforest and savannah, Environ. Sci. Technol., 29, 486-493, 1995.

Cao, J. J., Lee, S. C., Ho, K. F., Zou, S. C., Fung, K., Li, Y., Watson, J. G., and Chow, J. C.: Spatial and seasonal variations of atmospheric organic carbon and elemental carbon in Pearl River Delta Region, China. Atmos. Environ., 38, 4447-4456, 2004.

Conny, J. M. and Slater, J. F.: Black carbon and organic carbon in aerosol particles from crown fires in the Canadian boreal forest, J. Geophys. Res., 107(D11), 4116, doi:10.1029/2001JD001528, 2002.

Crutzen, P. J., Elansky, N. F., Hahn, M., Golitsyn, G. S., Brenninkmeijer, C. A. M., Scharffe, D. H., Belikov, I. B., Maiss, M., Bergamaschi, P., Röckmann, T., Grisenko, A. M., and Sevostyanov, V. M.: Trace gas measurements between Moscow and Vladivostok using Trans-Siberian railroad, J. Atmos. Chem., 29(2), 179-194, 1998.

Draxler, R. R. and Hess, G. D.: An overview of the HYSPLIT 4 modelling system for trajectories, dispersion and deposition, Aut. Met. Mag., 47, 295-308, 1998.

Hansen, A. D. A., Rosen, H., and Novakov, T.: The aethalometer: an instrument for the real-time measurement of optical absorption by aerosol particles, Sci. Total Environ., 36, 191-196, 1984.

Fraser, M. P. and Lakshmanan, K.: Using levoglucosan as a molecular marker for the long range transport of biomass combustion aerosols, Environ. Sci. Technol., 34, 4560-4564, 2000.

Iinuma Y., Brüggemann, E., Gnauk, T., Müller, K., Andreae, M. O., Helas, G., Parmar, R., and Herrmann, H.: The combustion of selected European conifers, African hardwood, savanna grass, and German and Indonesian peat, J. Geophys. Res., 112, D08209, doi:10.1029/2006JD007120, 2007.

Jalkanen, L. M. and Häsänen, E. K.: Simple method for the Dissolution of atmospheric aerosol samples for analysis by inductively 
coupled plasma mass spectrometry, J. Anal. At. Spectrom., 11, 365-369, 1996.

Kim Oanh, N. T., Upadhyay, N., Zhuang, Y.-H., Hao, Z.-P., Murthy, D. V. S., Lestari, P., Villarin, J.T., Chengchua, K., Co, H. X., Dung, N. T., and Lindgren, E. S.: Particulate air pollution in six Asian cities: Spatial and temporal distributions, and associated sources, Atmos. Environ., 40, 3367-3380, 2006.

Loo, B. W. and Cork, C. P.: Development of high efficiency virtual impactor, Aerosol Sci. Technol., 9, 167-170, 1988.

Ma, Y., Weber, R. J., Maxwell-Meier, K., Orsini, D. A., Lee, Y.-N., Huebert, B. J., Howell, S. G., Bertram, T., Talbot, R. W., Dibb, J. E., and Scheuer, E.: Intercomparisons of airborne measurements of aerosol ionic chemical composition during TRACE-P and ACE-Asia, J. Geophys. Res., 109, D15S06, doi:10.1029/2003JD003673, 2004.

National Atmospheric Emissions Inventory (NAEI): UK Emissions of Air Pollutants 1970 to 2001, National Environmental Technology Centre, Abington, UK, available at: http://www.airquality. co.uk/archive/reports/cat07/naei_report_1970-2001.pdf, 2003.

Oberlander, E., Brenninkmeijer, C. A. M., Crutzen, P. J., Elansky, N. F., Golitsyn, G. S., Granberg, I. G., Scharffe, D. H., Hofmann, R., Belikov, I. B., Paretzke, H. G., and Velthoven, P. F. J.: Trace gas measurements along the Trans-Siberian railroad: The TROICA 5 expedition, J. Geophys. Res., 107(D14), 4206, doi:10.1029/2001JD000953, 2002.

Orsini, D., Ma, Y., Sullivan, A., Sierau, B., Baumann, K., and Weber, R.: Refinements to the particle-into-liquid sampler (PILS) for ground and airborne measurements of water soluble aerosol composition, Atmos. Environ., 37, 1243-1259, 2003.

Penner, J. E., Quaas, J., Storelvmo, T., Takemura, T., Boucher, O., Guo, H., Kirkevåg, A., Kristjansson, J. E., and Seland, Ø.: Model intercomparison of indirect aerosol effects, Atmos. Chem. Phys. 6, 3391-3405, 2006.

Pinto, J. P., Lefohn, A. S., and Shadwick, D. S.: Spatial variability of $\mathrm{PM}_{2.5}$ in urban areas in the united states, J. Air Waste Manage., 54, 440-449, 2004.

Pope III, C. A. and Dockery D. W.: Health effects of fine particulate air pollution: Lines that connect, J. Air Waste Manage. Assoc., 56, 709-742, 2006.

Putaud, J.-P., Raes, F., Van Dingenen, R., Brüggemann, E., Facchini, M.-C., Decesari, S., Fuzzi, S., Gehrig, R., Hüglin, C, Laj, P., Lorbeer, G., Maenhaut, W., Mihalopoulos, N., Müller, K., Querol, X., Rodriguez, S., Schneider, J., Spindler, G., Ten Brink, H., Tørseth, K., and Wiedensohler A.: A European aerosol phenomenology - 2: chemical characteristics of particulate matter at kerbside, urban, rural and background sites in Europe, Atmos. Environ., 38, 2579-2595, 2004.

Querol, X., Alastuey, A., Ruiz, C. R., Artiñano, B., Hansson, H. C, Harrison, R. M., Buringh, E., ten Brink, H. M., Lutz, M., Bruckmann, P. Strael, P., and Schneider, J.: Speciation and origin of PM10 and PM 2.5 in selected European cities, Atmos. Environ., 38, 6547-6555, 2004.

Ramanathan V., Crutzen P. J., Kiehl J. T., and Rosenfeld D.: Aerosols, climate, and the hydrological cycle, Science, 294, 2119-2124, 2001.
Saarikoski, S., Mäkelä, T., Hillamo, R., Aalto, P., Kerminen, V.-M., and Kulmala, M.: Physico-chemical characterization and mass closure of size segregated atmospheric aerosols in Hyytiälä Finland, Boreal Environ. Res., 10, 385-400, 2005.

Saarikoski, S., Sillanpää, M., Sofiev, M., Timonen, H., Saarnio, K., Teinilä, K., Karppinen, A., Kukkonen, J., and Hillamo, R.: Chemical composition of aerosols during a major biomass burning episode over northern Europe in spring 2006: experimental and modelling assessments, Atmos. Environ., 41, 3577-3589, 2007.

Sillanpää, M., Hillamo, R., Saarikoski, S., Frey, A., Pennanen, A., Makkonen, U. Spolnik, Z.,Grieken, R., Branis, M., Brunekreef, B., Chalbot, M.-C, Kuhlbusch. T., Sunyer, J., Kerminen, V.-M., Kulmala, M., and Salonen, R. O.: Chemical composition and mass closure of particulate matter at six urban sites in Europe, Atmos. Environ., 40, S212-S223, 2006.

Simoneit, B. R. T., Schauer, J. J., Nolte, C. G., Oros, D. R., Elias, V. O., and Fraser, M. P.: Levoglucosan, a tracer for cellulose in biomass burning and atmospheric particles. Atmos environ, 33, 173-182, 1999.

Song, X.-H., Polissar, A. V., and Hopke, P. K.: Sources of fine particle composition in the northeastern US, Atmos. Environ. 35, 5277-5286, 2001.

Stohl, A., Berg, T., Burkhart, J. F., Fjaeraa, A. M., Forster, C., Herber, A., Hov, Ø., Lunder, C., McMillan, W. W., Oltmans, S., Shiobara, M., Simpson, D., Solberg, S., Stebel, K., Ström, J., Tørseth, K., Treffelsen, R., Virkkunen, K., and Yttri, K. E.: Arctic smoke - record high air pollution levels in the European Arctic due to agricultural fires in Eastern Europe in Spring 2006, Atmos. Chem. Phys., 7, 511-534, 2007.

Tunved, P., Hansson, H. C., Kerminen, V.-M., Ström, J., Dal Maso, M., Lihavainen, H., Viisanen, Y., Aalto, P. P., Komppula, M., and Kulmala, M.: High natural aerosol loading over boreal forests, Science 312, 261-263, 2006.

Vartiainen, E., Kulmala, M., Ehn, M., Hirsikko, A., Junninen, H., Petäjä, T., Sogacheva, L., Kuokka, S., Hillamo, R., Skorokhod, A., Belikov, I., Elansky, N., and Kerminen, V.-M.: Ion and particle number concentrations and size distributions along the TransSiberian railroad, Boreal, Env. Res., 12, 375-396, 2007.

Watson, J. G.: Visibility: Science and regulation, J. Air. Waste Manage. Assoc., 52, 628-713, 2002.

Winklmayr, W., Reischl, G. P., Linder, A. O., and Berner, A.: A new electromobility spectrometer for the measurement of aerosol size distributions in the size range from 1 to $1000 \mathrm{~nm}$, J. Aerosol Sci., 22, 289-296, 1991.

Yamasoe, M. A., Artaxo, P., Miguel, A. H., and Allen, A. G.: Chemical composition of aerosol particles from direct emissions of vegetation fires in the Amazon Basin: water-soluble species and trace elements, Atmos. Environ., 34, 1641-1653, 2000.

Yu, H., Kaufmann, Y. J., Chin, M., Feingold, G., Remer, L. A., Anderson, T. L., Balkanski, Y., Belloin, N., Boucher, O., Christopher, S., DeCola, P., Kahn, R., Koch, D., Loeb, N., Reddy, M. S., Schulz, M., Takemura, T., and Zhou, M.: A review of measurement-based assessment of the aerosol direct radiative effect and forcing, Atmos. Chem. Phys. 6, 613-666, 2006. 